\title{
Migrant Women's Social Contruction In The Pontang Sub District Of Banten Province
}

\author{
R Mulyasih ${ }^{1}$, F Habibi ${ }^{2}$ \\ ${ }^{1,2}$ Universitas Serang Raya, Banten \\ 1bikiya16@gmail.com, ${ }^{2}$ fikrihabibi81@gmail.com
}

\begin{abstract}
Migrant women or formerly known as Women Workers (TKW), are part of the portrait of social life in Indonesia. The majority of these women work based on the economic crush that results in these women being forced to work leaving their families. The purpose of the research on migrant women is based on the researcher's curiosity about the motives of migrant women when she decides to work as a migrant women, then it also looks at the meaning of migrant women when she positions as a wife, mother and community member and the experience of migrant women after she works in overseas. The research method used in this research leads to the phenomenological research method, which in this method emphasizes more on studies that explain and classify phenomena or study of visible phenomena. The results of the study found that there are different motives and experiences felt by each migrant woman in the Sub District of Pontang based on the self-understanding that exists in each migrant women in the Sub District of Pontang, due to the social construction that afflicts both migrant women that she gets from the community environment and family.
\end{abstract}

Keywords: Migrant Women, Social Construction, Meanings, Experience.

\section{INTRODUCTION}

Migrant workers in which women are known as TKW are part of the portrait of social life in Indonesia. The women decided to become migrant workers because of poverty. Poverty is indeed the strongest reason in deciding to work and go abroad, although on the other hand they have to leave the family [1] states that women everywhere devote their energy to preserving their families, educating their children, caring for sick family members, and even outside the household women play a role in community welfare efforts.

But not so with the families of migrant women, migrant women must be brave enough to take the risk of leaving the family to strengthen the family's economy due to family conditions that require them to work abroad, whereas according to [2] further explains that women show themselves as creatures that have more compassion and sympathy, are more afraid or shy, are more talkative, sensitive to beauty, then generally more emotional, morally harder, weaker in controlling their emotions and physically less strong. Instead men are culturally depicted as having hard, active, strong, rational, aggressive traits and other traits that ultimately give men the image of being tough and hard. Men (both direct and indirect) generally exhibit greater selfassertiveness and aggressiveness, they are more stoic and less fearful, and are more violent in their behavior, language and feelings. With this presentation, it means that women are people who should be at home instead of working outside replacing the role of men as head of the family at home, not to mention if we look at news in various print and new media that illustrates 
the amount of torture and uncertain fate. due to the lack of strict government policies regarding the protection of migrant women, many migrant women are victims of sexual harassment or human trafficking.

With so many problems faced by migrant women, it does not cause the community to turn away from becoming migrant women because until now working as a migrant woman is one of the dreams of girls whose villages are pockets of migrant women's distributors, including one in the Pontang Sub District of Banten Province. Pontang Sub District is an area where many people work as migrant women and even one of the villages in this region is called "Kampung Dollar" because most members of the community in this village work as migrant women, so that the community hopes that many dollars will come to this village so that it can prosper the community. Welfare and stability of life are the biggest dreams of every community, therefore the departure of a family member as a migrant woman is aimed at improving the family's economy. Although on the other hand many other problems arise as a result of their decision to become a migrant woman, such as a change in position or role in the family between husband and wife.

The life of the community in general, who works for a living is a husband because the husband is the head of the family who must provide for his family's needs and the wife who takes care of family needs. But in the lives of migrant women the position and role changes in this case the husband is no longer a breadwinner but has been replaced by a wife who works and provides family needs. It is this change in role which then creates a new social phenomenon from the culture of society where there is a meaning drawn from each migrant woman in seeing herself as a woman who acts as a wife, mother and community members. According to Hasuri (12 November 2018), one of the community leaders in Domas Village, one of the well-known villages as migrant women's villages stated that the change in roles between husband and wife had indeed taken place in the community and it had lasted long enough so that the community saw it as normal. There have been a number of cases told by Hasuri about this changing role, for example there was a family left by his wife to go abroad to become a migrant woman so the domestic work that should be done by the wife was replaced by the husband or wife's family, but there was also a husband who later remarried so that children whose families are taken care of, and in the end the phenomenon of divorce becomes a common thing in their environment.

In contrast to what Hasuri said, Yuyun (5 December 2018) who is a former migrant woman said that there had indeed been a change in roles when she worked abroad, such as in deciding everything needed in family needs such as investing in the results of her work as a a migrant woman, or even in buying a vehicle. Researchers do see that family members who become migrant women have a nice and luxurious home complete with luxurious household furniture. In the past, before becoming a migrant woman, her house was normal, but after becoming a migrant woman, their houses turned into nice and luxurious homes. This phenomenon then results in the desire of every member of the community for their daughters to work as migrant women, even in this region there is a tendency for the community to want to have daughters rather than boys because according to them girls can improve the family economy by becoming a migrant woman.

The motive for improving the family's economy is the biggest motive for migrant women who decide to work abroad, but there is another motive besides the motive for poverty, which is the motive to run away from problems faced by families such as domestic conflicts. But to reach an understanding of her role and position as a wife in the family and community, a deeper understanding of her meaning as a woman is needed. Phenomenally women who work as migrant women have the same experience as how they work abroad, but the level of understanding of each individual in interpreting the content or substance they provide for the 
experience is certainly different because it depends on the stock of knowledge they have as individuals.

So that researchers want to examine the meaning they give to the meaning of women in the lives of migrant women, therefore researchers use a phenomenological approach as a medium to analyze data from the field for the purposes of this study. Phenomenology will greatly help researchers to understand women migrants subjectively, due to differences in interpreting their roles and positions in the family and community. While the theory used is the Social Construction Theory of Reality according to Berger and Luckman is defined as a process through actions and interactions and interactions where individuals create continuously from the reality that is shared and subjectively experienced together [3]

But on the other hand the understanding and interpretation of women from workers in this case migrant women also affect their children, because no matter how a child really needs the presence of his mother as their first school, because the training of a mother must be different from the training of a father. This is consistent with what Hasuri said that states that there is indeed a different education between father and mother, where if a father always has a practical mind so that the child wants anything to be fulfilled, it is different from the training of a mother who will consider the pros and cons of a child's request. So in the end the children of migrant women desperately need a mother's love.

Based on the description and presentation that has been raised by the researcher, this study will raise the theme of "Construction of the Meanings of Women in Communities in the Pontang Sub District of Banten Province".

\section{RESEARCH METHOD}

The research method used in the study of "Social Construction of Migrant Women in the Pontang Sub District", uses the phenomenology method wherein phenomenology is more directed towards science (logos) about the Apparent (phenomenon), so that phenomenology is a reality that is seen in the perception of each individual [4].

The assumption of the phenomenological research method is that people will actively interpret their experiences by giving meaning to what they see so that the interpretation process is a major aspect of the phenomenology method, therefore in the phenomenology perspective it tends to have a priori principles, meaning that phenomenology research is initiated and based on the existence of certain theories so that the study of phenomenology is more directed to "what is observed" and "how to observe it".

According [5] explained that the basis of phenomenology is more directed to the structure of types of consciousness, which ranges from perceptions, ideas, memory, imagination, emotions, desires, desires to social actions or in the form of language so that in phenomenological research description the data developed was obtained from all individual structural descriptions that represented group experiences. Thus the merging of group textural and structural descriptions that provides synthesis of meaning and essence.

\section{RESULTS AND DISCUSSION}

The process of interaction that occurs between migrant women with their families and communities produces a social construction that can affect both the cognitive, affective and conative aspects of the migrant woman herself. According to [6] humans in carrying out social actions based on the experience, meaning and awareness. So that in carrying out social interactions, migrant women cannot be separated from the social actions of people in their environment, starting from the significant others (closest people such as family and friends) to 
the general public regarding their decision to work abroad. The decision to work abroad is certainly not easy for women migrants, especially for migrant women who already have families and children. Because after all a mother may not be able to part with her children in a long time, because usually migrant women will be contracted to work abroad for at least 2 (two) years.

According to [7] Indonesian society is patriarchal, which positions women who have to respect men so they think that men should protect women because they are seen as weak women so that men become the regulator of women. But with modernization women are encouraged to be involved in the family economy, as explained by Nanda and Warms in [8] stating that "More and more women are participating in the world economy. With this there is an impact on changes in position and role both economically and domestically in the family.

The responses and views of the people around who then made migrant women assess and interpret themselves, interpret their motives for deciding to work abroad. Mead in [9] defines ourselves as the ability to reflect on ourselves from the perspective of others. So Mead called it a mirror of self or the ability to see ourselves in the eyes of others believes in three principles of development that are linked to self-mirrors we imagine how we look in the eyes of others, we imagine their judgment about our appearance and we feel hurt or proud based on personal feelings. In other words we are required to learn about ourselves from the way other people treat us, view us and label ourselves.

To become a migrant woman, is not a very short process in deciding to work abroad. This process occurs because there are several stages so that migrant women decide to work abroad beginning with the construction received by prospective migrant women from the surrounding environment as migrant girls' children are usually exposed to by the phenomenon of women working abroad such as mothers them, neighbors, and relatives. So that the children do not feel burdened when they decide to work abroad. It is through this environment that migrant women interpret their motives for working abroad or by the term self-mirror, where migrant women see themselves as based on two mirrors, the first mirror is called the internal environment and the second mirror is referred to as the external environment. The supporting internal environment is in the form of experience and knowledge based on observations of daily life, while the external environment is a self-assessment resulting from interactions with family and the surrounding environment that gives birth to the main motives or the most powerful motives for migrant women to decide to work abroad.

Therefore, in understanding why migrant women decide to work abroad, they must first know their motives, and based on observations there are a number of factors underlying the migrant women's decision to work abroad, including:

\section{a. Motives for a Better Life}

The motive for a better life in terms of an improved economy, is a major factor why migrant women decide to work abroad. This is because, the Pontang region is a coastal area that is still relatively difficult to find employment. Even if there is more land to work for fishermen or make Pontang typical food from fish preparations called Bontot. However, the income that people get from being fishermen and food processing makers is very little so that people look for other alternatives to meet their daily needs.

Being a migrant woman is one of the things that is interesting for most women in the Pontang region. It is very rare for women in the Pontang region to choose to remain ordinary housewives. This attraction, because migrant women who have just returned to work from abroad, usually come home with a lot of gold attached to their hands and neck not to mention the magnificent house built when the migrant woman returned to her hometown. With this phenomenon, forming social construction on other 
women to work abroad and become migrant women, because of the attraction presented by migrant women who have worked and returned to their hometowns.

Being a migrant woman is one of the interesting things. This is as expressed by Mariam as follows:

I am interested in becoming a migrant woman because of lack of income, because my husband is unemployed while my child has to go to school. To become a migrant woman, the salary is around 5 million, if the old can reach 8 million, so it can make household needs and venture capital if it's no longer a migrant woman. (August 16, 2019)

The limitation of land for work that is not evenly distributed in the area has resulted, for example, women in the Pontang area do not have other options, although many things that these women must sacrifice such as the necessity in leaving their families, especially their children. In the end, the position and role of migrant women must be replaced by those around her, such as the closest family, in this case, mostly replaced by their grandmothers. Therefore there is a need for good handling from the government, especially to deal with the limited land available in the regions so that the attraction to become a migrant woman is no longer in the minds of women in rural areas, because after all good education for the next generation is in the hands mothers.

\section{b. Motive of Appreciation or Self-Esteem}

The decision to become a migrant woman is much influenced by the social construction formed by the community, where the community values women who work as migrant women. This is because the community thinks that becoming migrant women is a successful woman because of the many established lives displayed by migrant women when they return home from abroad. So from this, then many parents in the Pontang region who want to have a daughter than a son. Because when they have a daughter, the child can raise the family economy by working abroad. This is as expressed by Maman, a community leader in the Pontang District region with the following explanation:

Most parents in Pontang, prefer girls. The problem is that it can

lift the dignity of the family, so parents are helped if their

children can work abroad to become migrant workers (September 19, 2019)

Therefore being a migrant woman is a prestige among the women in the Pontang region.

\section{c. Running Motives From Life Problems}

The problems that are experienced by many women in rural areas before deciding to become migrant women initially were economic problems, but after the economic problems were resolved there were new problems arising from the decision to work abroad, namely the complexity when she returned home with her husband's position still unemployed or the hubbub of children they are not used to facing because they have not taken care of the household for a long time. In the end, these migrant women feel at home to remain migrant women, so from the results of the study there are migrant women who have worked for 30 years (thirty years).

Humans give meaning to everything that exists in the surrounding environment through the process of social interaction it does. The meaning then experiences development, evolves, has a dynamic nature so that the individual gives meaning to the reality around him consciously 
through the process of interpreting objective reality. In this case, migrant women interpret the objective reality that surrounds them subjectively by interacting with the reality that appears in the lives of migrant women.

The results showed that the average research informant interpreted herself as a migrant woman differently. Some feel that when she becomes a migrant woman her life is above her husband because she works and supports her family, then this migrant woman decides to use the fruits of her labor to be invested in anything and for any needs other than that of household problems it was decided by migrant women in positions as wives. This is an unusual view for family life in Indonesia in general, because for families in Indonesia, women are usually in the second class position after men, so the deciding everything that happens in domestic life is the husband or men. This is as expressed by Sumiyati, a migrant woman who has worked in Saudi Arabia for 10 (ten) years as follows:

To renovate the house, buy a vehicle, well, I told the husband. So when I transfer I say to my husband, the money is for anything and the husband also if you need anything must be approved by me, I'm the one who works. (September 19, 2019)

But there are also those who interpret it differently, even though she has become a migrant woman, her role and position as a wife must still be in the position of respecting and respecting her husband even though he has economic power compared to her husband. So when he returns from work abroad, his position and role as a wife, mother and community members will return to normal life before he becomes a migrant woman. Because basically the core of the meaning of marriage for migrant women lies in the interaction with her husband and children, so the husband's treatment of him forms an understanding of the husband's behavior patterns and behavior, but the association during his work abroad did not rule out the possibility of influencing migrant women's behavior to her husband and children. This is consistent with what is expressed by Tuti, as follows:

I used to say that anything is always up to the husband, because after all the husband knows the needs at home. Only if now, after the husband caught cheating, all I set. I also transfer the money to the mother or not to my husband again (September 20, 2019)

From what has been disclosed by the informants it can be concluded that each migrant woman has a different meaning regarding her role and position as a wife, mother and community members. Although each migrant woman experiences a process of adaptation both when she becomes a migrant woman and when she has returned from working abroad. The process of adaptation according to social construction theory can create a pattern of reciprocity that is understood by one another in a process of daily interaction. This reciprocity can then produce a form of habit that enables migrant women to be able to predict the actions that will be taken to behave to their husbands, children and also to people in the surrounding environment. This predictable interaction is what according to [10] can make it easier for women migrants to deal with one another, saving time and energy, especially in saving from the burden of psychological tension and excessive anxiety.

This is very much in accordance with what is felt by informants who have difficulty in adapting to their husbands and children, especially when migrant women have returned to their hometowns. Children abandoned by their mothers, when they are young, are likely to feel alien when their mothers return from working abroad so that adaptation is needed to explore children's memories of the mother's position in their hearts so that the children of migrant women can accept their mother's presence well even though they are not fully cared for by a mother. Likewise, the adaptation made by migrant women to their husbands, where when less intense 
communication is carried out by migrant women and their husbands when they are far apart results in a change in communication patterns, so re-adaptation is needed so that it is possible for them to create effective communication between the two. Because after all the communication that is not well established, can result in household collapse in the lives of migrant women.

\section{CONCLUSIONS}

Migrant women have a unique phenomenon in their lives, not only due to the complex family life but also to the changes brought when they go home after working from abroad. And these changes are not only on social change but also cultural change, so that the changes brought about in the end construct the environment both the community and their families but also construct themselves as migrant women, wives, mothers and also members of the community.

Therefore it is necessary for the role of the Government, Community Leaders, Ulama to fortify the culture brought by migrant women, lest the culture that normally exists in our society be completely eroded by the culture that is brought by migrant women. And there is special attention, especially from institutions that deal with migrant women to provide knowledge and insights on the importance of the role of the wife in the structure of domestic life, which when viewed from a religious perspective even though economically the husband's position for the domestic life of migrant women under his wife, must still exist appreciation, respect and love for each other so that divorce rates in the domestic lives of migrant women can be suppressed.

In addition, migrant women must also be given the views of several parties both the Government and community leaders that, when they decide to work abroad, they must have careful planning and targets for how long they will work. So do not let the money they get is used up for the needs of the people around him such as husband, children and family needs. In the end, migrant women cannot be empowered for themselves when they no longer work abroad, because they do not have other skills and their money is always used up, so they always think of returning as migrant women for years or even decades.

\section{REFERENCES}

[1] S. Suryochondro, Timbulnya dan Perkembangan Gerakan Wanita di Indonesia. Jakarta: Yayasan Obor Indonesia, 1995.

[2] Collins, Black feminist thought: Knowledge, consciousness and the politics of empowerment. New York: Routledge, 1987.

[3] M. Paloma, Sosiologi Kontemporer. Yogyakarta: Tim Penerjemah Yosagama, 1994.

[4] L. John, W. Stephen, and K. A. Foss, Teori Komunikasi. Jakarta: Salemba Humanika, 2009.

[5] E. Kuswarno, Fenomenologi. Bandung: Widya Padjadjaran, 2009.

[6] A. Schutz, The Phenomenological of The Social World. Northwestern: USA: Northwestern University Press., 1967.

[7] B. T. Adeney, Etika Sosial Lintas Budaya. Yogyakarta: Kanisius Yogyakarta, 2004.

[8] L. Samovar, R. Porter, and E. R. McDaniel, Komunikasi Lintas Budaya. Jakarta: Salemba Humanika, 2011.

[9] R. West and L. H. Turner, Pengantar Teori Komunikasi: Analisis dan Aplikasi. Jakarta: Salemba Humanika, 2009.

[10] P. L. Berger and T. Luckmann, The Social Construction of Reality: A Treatise in The Sociology of Knowledge. Harmondswirth: Harmondswirth: Penguin Books Ltd., 2012. 
